\title{
PERANAN SELF-REGULATED LEARNING DALAM PENDEKATAN KONSTRUKTIVISME DALAM KERANGKA IMPLEMENTASI KURIKULUM TAHUN 2013
}

\author{
Dahlia Novarianing Asri *)
}

\begin{abstract}
Abstrak
Pendidikan dan pembelajaran di sekolah dapat dipandang sebagai suatu sistem. Di dalamnya terdapat beberapa komponen yang saling berinteraksi, yaitu siswa, guru, kurikulum, administrasi, fasilitas penunjang dan lingkungan belajar. Setiap komponen pembelajaran tersebut mempunyai peranan dan fungsi masingmasing yang mendukung keseluruhan sistem pendidikan dan pembelajaran di sekolah dalam mencapai tujuan yang telah ditetapkan.

Dalam pengertian pendidikan dan pembelajaran sebagai suatu sistem sebagaimana yang telah dikemukakan di atas, kurikulum dipandang sebagai salah satu komponen yang paling penting. Implementasi Kurikulum 2013 mendorong siswa mampu melakukan kegiatan eksplorasi dan hal ini ber-implikasi terhadap pelaksanaan kegiatan pembelajaran yang menerapkan berbagai strategi dan metode pembelajaran yang menyenangkan, kontekstual, efektif, dan bermakna.

Salah satu inovasi pembelajaran menuju student centered adalah pendekatan konstruktivisme. Dalam pendekatan konstruktivisme, siswa harus membangun pengetahuan dalam kerangka berpikirnya. Guru dapat memfasilitasi proses dalam mengajar dengan cara memberikan informasi yang bermakna dan relevan kepada siswa. Salah satu konsep dalam pendekatan konstruktivisme adalah self-regulated learning. Dalam self-regulated learning, siswa perlu diarahkan untuk mengatur diri sendiri dan berperan mengevaluasi kemajuan siswa, dan bertindak melampaui standar-standar yang disyaratkan bagi mereka dengan menelusuri hal-hal yang menjadi minat mereka. Self-regulation bukanlah suatu kemampuan mental atau keterampilan performance akademik, melainkan suatu proses self-directive dimana siswa mengubah kemampuan mental mereka ke dalam keterampilan akademik.
\end{abstract}

Kata kunci : Self-Regulated Learning, Konstruktivisme, Kurikulum 2013

* Dahlia Novarianing Asri adalah Dosen Program Studi Bimbingan dan Konseling Fakultas Ilmu Pendidikan IKIP PGRI Madiun. 


\section{A. Pendahuluan}

Pendidikan dan pembelajaran di sekolah dapat dipandang sebagai suatu sistem. Di dalamnya terdapat beberapa komponen yang saling berinteraksi, yaitu siswa, guru, kurikulum, administrasi, fasilitas penunjang, dan lingkungan belajar. Setiap komponen pembelajaran tersebut mempunyai peranan dan fungsi masingmasing yang mendukung keseluruhan sistem pendidikan dan pembelajaran di sekolah dalam mencapai tujuan yang telah ditetapkan. Di samping itu, komponenkomponen tersebut saling berhubungan dalam posisi interdependensi, dalam arti bahwa pelaksanaan fungsi masing-masing komponen tersebut dalam suatu sistem tidak terlepas dari fungsi komponen-komponen yang lain. Ini berarti bahwa jika suatu komponen tidak dapat melaksanakan fungsi dan perannya sebagaimana mestinya, akan berpengaruh terhadap pelaksanaan fungsi dan peranan komponenkomponen yang lain dan akhirnya akan mengganggu keseluruhan sistem tersebut.

Dalam pengertian pendidikan dan pembelajaran sebagai suatu sistem sebagaimana yang telah dikemukakan di atas, kurikulum dipandang sebagai salah satu komponen yang paling penting. Hal ini berdasarkan kenyataan bahwa dalam melaksanakan kegiatan belajar mengajar sehari-hari, mulai dari menyusun perencanaan pembelajaran, menyajikannya di depan kelas, sampai melaksanakan evaluasi hasil belajar, kurikulum merupakan pedoman utama yang dijadikan acuan oleh para guru.

Menurut Sujoko (2002:1), kurikulum yang merupakan rencana dan pelaksanaan pendidikan mempunyai sifat yang selalu dinamis dan senantiasa dipengaruhi oleh perubahan-perubahan dalam faktor-faktor yang mendasarinya. Perubahan tujuan pendidikan akan berakibat pada perubahan kurikulum. Kurikulum dapat pula mengalami perubahan bila terdapat pendirian baru mengenai proses belajar mengajar. Perubahan dalam masyarakat, eksplorasi ilmu pengetahuan, dan lain-lain mengharuskan adanya perubahan kurikulum.

Agar perubahan kurikulum dapat sesuai dengan kebutuhan dan perkembangan masyarakat maka pihak yang berwenang mengembangkan kurikulum harus bekerja sama dengan pemakai lulusan untuk memberikan masukan mengenai format lulusan yang ingin dicapai. Dengan demikian, lulusan 
yang dihasilkan nantinya akan sesuai dengan apa yang dibutuhkan oleh "pasar" yang akan memakainya.

Menurut Farozin (2014:1), kurikulum merupakan salah satu komponen pendidikan yang sangat penting dan bila terjadi perubahan atau pengembangan terhadap kurikulum, maka akan berdampak pada penataan komponen pendidikan lainnya. Kurikulum merupakan seperangkat rencana dan pengaturan mengenai tujuan, isi, dan bahan pelajaran, serta cara yang digunakan sebagai pedoman penyelenggaraan kegiatan pembelajaran untuk mencapai tujuan pendidikan tertentu.

Sumantri (2004:27), menyatakan bahwa pengembangan kurikulum tidak dapat terlepas dari berbagai aspek kehidupan dan faktor-faktor yang mempengaruhinya, mulai dari pemikiran sampai pada pelaksanaannya, agar kurikulum itu sesuai dengan kebutuhan masyarakat. Usaha pembaruan kurikulum merupakan hal yang wajar terjadi. Secara teoretis, setiap jangka waktu tertentu perlu diadakan perubahan kurikulum agar kurikulum tersebut dapat mengakomodasikan aspirasi yang berkembang di kalangan masyarakat serta dapat mengikuti perkembangan ilmu pengetahuan dan teknologi. Dengan demikian, kurikulum yang dipergunakan tetap memiliki relevansi yang tinggi dengan kebutuhan masyarakat serta perkembangan ilmu pengetahuan dan teknologi.

Dalam konteks pengembangan kurikulum, mulai tahun 2013 pemerintah akan memberlakukan kurikulum baru yang disebut dengan Kurikulum 2013. Pelaksanaan Kurikulum 2013 oleh pemerintah dipandang sebagai keharusan yang mendesak, walaupun jika ditilik dari segi persiapan masih belum sempurna, bahkan dapat dikatakan mengkhawatirkan. Alasan utama pentingnya pemberlakuan Kurikulum 2013 adalah bahwa generasi muda Indonesia perlu disiapkan dalam kompetensi sikap, keterampilan, dan pengetahuan.

Alasan lain dikemukakan oleh Triyono (2014:2) yang menyatakan ada sejumlah perubahan yang harus dihadapi bangsa ini dalam mencerdaskan bangsanya. Kondisi global dan globaltan kerja, perubahan karakter, adanya perunahan tuntutan persyaratan yang mendorong perlunya perubahan kompetensi lulusan sekolah. Secara global, lulusan kita jauh tertinggal dengan lulusan dari negara-negara lain, termasuk negara-negara Asia-Pasifik. Sejalan dengan pasar 
bebas yang sebentar lagi dijalankan, dikhawatirkan lulusan sekolah kita tidak mampu bersaing di tingkat global, bahkan di tingkat lokal yang akan digelontor lulusan dari negara lain. Upaya pendidikan saat ini dikandung maksud untuk mempersiapkan insan Indonesia yang produktif, kreatif, inovatif, dan afektif serta berkontribusi pada kehidupan bermasyarakat, berbangsa, bernegara, dan peradaban dunia. Kurikulum 2013 digagas untuk memenuhi tuntutan tersebut di atas.

Implementasi Kurikulum 2013 mendorong siswa mampu melakukan kegiatan eksplorasi dan hal ini berimplikasi terhadap pelaksanaan kegiatan pembelajaran yang menerapkan berbagai strategi dan metode pembelajaran yang menyenangkan, kontekstual, efektif, dan bermakna. Pada gilirannya, kegiatan pembelajaran diharapkan mampu mengembangkan dan meningkatkan kompetensi, kreativitas, kemandirian, kerjasama, solidaritas, kepemimpinan, empati, toleransi, dan kecakapan hidup peserta didik guna membentuk watak serta meningkatkan peradaban dan martabat bangsa.

Siswa yang bersifat otonom perlu diberi kesempatan untuk menemukan sendiri dan mentransformasikan informasi kompleks, mengecek informasi baru dengan aturan-aturan lama di dalam benaknya, dan merevisinya apabila aturanaturan itu tidak lagi sesuai. Peserta didik harus didorong merekonstruksi pengetahuan melalui pengalaman-pengalamannya. Dengan demikian, Kurikulum 2013 sejalan dengan paradigma konstruktivisme dalam ilmu pendidikan.

\section{B. Pengembangan Kurikulum Tahun 2013}

Abad keduapuluh satu ini adalah masa di mana perkembangan ilmu dan teknologi sangat pesat perkembangannya dan tidak tertandingi oleh perkembangan pada masa sebelumnya. Perkembangan ini mempengaruhi nilai dan norma yang dianut masyarakat. Jika dalam masa sebelumnya pengetahuan dan ilmu tentang politik, hukum, dan budaya adalah lambang keterpelajaran seseorang, sekarang ini ada warna baru dalam masyarakat. Teknologi menjadi paradigma yang diagungkan. Tentu saja sikap ini memberikan tuntutan baru terhadap pendidikan pada umumnya dan pembaruan kurikulum pada khususnya.

Perkembangan ilmu dan teknologi yang pesat meminta kewaspadaan yang tinggi bagi mereka yang terlibat dalam pengembangan dan evaluasi 
kurikulum. Evaluasi kurikulum harus dapat memberikan informasi yang berkesinambungan mengenai keselarasan kurikulum dengan perkembangan masyarakat. Evaluasi kurikulum harus dapat menentukan apakah kurikulum yang ada masih relevan dengan perkembangan masyarakat, terlepas dari keberhasilan dalam unjuk kerja yang diperlihatkannya. Penilaian terhadap kurikulum harus dapat mencegah terjadinya apa yang dikenal dengan istilah "sabertooth curriculum". Keausan kurikulum harus dapat segera dikenali sehingga perubahan atau perbaikan kurikulum dapat dilakukan (Hasan, 2004:179).

Sesuai dengan peran yang dimainkan pemerintah dalam pengembangan dan pelaksanaan kurikulum maka pemerintah memiliki kewajiban politik, moral, dan juga sosial untuk menyesuaikan kurikulum dengan berbagai dimensi tuntutan. Untuk itu, pemerintah memerlukan berbagai informasi evaluatif mengenai kurikulum yang berlaku.

Dalam usaha pengembangan dan pembaruan kurikulum terdapat sejumlah prinsip dasar yang dipakai sebagai landasan agar kurikulum yang dihasilkan memenuhi keinginan yang diharapkan, baik oleh pihak sekolah, murid, orang tua, masyarakat, maupun pemerintah. Prinsip-prinsip dasar yang biasanya dianut dalam pengembangan dan pembaruan kurikulum berasal dari berbagai sumber pandangan yang berasal dari pandangan filsafat, pendidikan, psikologi, sosiologi, manajemen, ekonomi, ideologi, dan sebagainya.

Sumber pandangan mana yang menjadi prioritas utama antara negara yang satu dengan negara yang lain tidaklah sama. Pada negara tertentu misalnya, prinsip ideologi dan politik mungkin dijadikan prioritas utama, sedangkan negaranegara lain menggunakan filsafat dan agama. Pada negara-negara berkembang seperti Indonesia, prinsip pembangunan dan kesejahteraan sosial paling mewarnai pembaruan dan pengembangan kurikulum. Pada negara yang telah maju dan telah mapan kehidupan ekonominya, prinsip-prinsip psikologi yang mendukung pengembangan individu secara optimal menjadi komponen-komponen pembaruan dan pengembangan kurikulum. Namun, para pembaru dan pengembang kurikulum tidak dapat melepaskan satu prinsip, yaitu prinsip modernisasi. Implikasi prinsip tersebut adalah agar materi kurikulum bersumber pada ilmu pengetahuan dan 
teknologi modern. Di samping itu, juga dimaksudkan agar materi kurikulum selalu berada dalam proses pembaruan dan dapat mencakup perkembangan iptek.

Menurut Tedja (2004:78-79), dalam usaha untuk meningkatkan mutu pendidikan, pengembangan kurikulum ditentukan oleh faktor-faktor: (1) filosofis atau kefilsafatan, (2) sosiologis atau kemasyarakatan, (3) psikologis atau kejiwaan, (4) saintifis atau keilmuan, dan (5) skilfuli atau keterampilan. Senada dengan pendapat tersebut adalah pendapat Sukmadinata (2003: 24-61), yang menyatakan bahwa pengembangan kurikulum akan mampu meningkatkan kualitas pendidikan apabila disusun berdasarkan landasan-landasan yang kuat, yang didasarkan atas hasil pemikiran dan penelitian yang mendalam. Landasanlandasan yang dimaksud meliputi landasan: filosofis, psikologis, sosial budaya, serta perkembangan ilmu dan teknologi.

Di samping prinsip-prinsip dan landasan-landasan pengembangan kurikulum yang telah disebutkan di depan, pengembangan kurikulum dalam proses pendidikan harus mempertimbangkan beberapa hal. Pertama adalah filsafat hidup bangsa, dalam hal ini adalah Pancasila. Hal ini berarti bahwa segala kegiatan di sekolah harus diarahkan pada pembentukan pribadi peserta didik ke arah manusia Pancasilais. Kedua adalah pertimbangan harapan, kebutuhan dan atau permintaan masyarakat akan produk pendidikan. Hal ini berarti bahwa azas relevansi pengembangan kurikulum harus dijaga, termasuk kondisi masyarakat lokal. Ketiga adalah kesesuaian kurikulum dengan kondisi peserta didik. Oleh karena itu, dalam pengembangan kurikulum harus memperhatikan karakteristik peserta didik, baik karakteristik yang bersifat umum maupun yang bersifat khusus. Keempat adalah kemajuan ilmu pengetahuan, yang berarti pengembangan kurikulum harus berisi dan disesuaikan dengan perkembangan iptek (Subandijah, 2003:37).

Pada prinsipnya, pengembangan kurikulum dimulai dengan suatu proses perencanaan, yaitu menetapkan berbagai kebutuhan, mengadakan identifikasi tujuan dan sasaran, menyusun persiapan dan pelaksanaan penyajian yang sesuai dengan segala persyaratan kebudayaan, sosial dan pribadi. Karena itu, perencanaan pembaruan kurikulum harus disertai dengan analisis yang berkaitan 
dengan berbagai akibat pendekatan-pendekatan yang dilakukan sebelum penyajian tersebut dilaksanakan.

Pelaksanaan pembaruan kurikulum tersebut menuntut kesiapan dari semua pihak yang terkait dengan kegiatan pembelajaran di sekolah, terutama para guru karena mereka inilah yang menjadi ujung tombak pelaksanaan pembaruan kurikulum. Seperti yang dinyatakan Suwandi (2009:24) bahwa sebagai input instrumental, kurikulum yang baik belum menjamin mutu pendidikan akan baik pula. Mutu proses dan hasil pendidikan akan lebih banyak bergantung pada guru sebagai pihak yang mengimplementasikan kurikulum dalam praktik pembelajaran.

Kesiapan para guru terhadap pembaruan kurikulum antara lain dapat berupa sikap terbuka dan mau menerima pembaruan kurikulum sebagai sesuatu yang wajar, bahkan sesuatu yang seharusnya dilakukan. Adanya sikap terbuka dan mau menerima pembaruan itu sangat penting karena dengan demikian para guru akan berusaha memahami kurikulum yang baru itu serta berusaha melaksanakannya dalam kegiatan pembelajaran dengan sebaik-baiknya.

Berkaitan dengan perubahan kurikulum, berbagai pihak menganalisis dan memandang perlunya diterapkan kurikulum berbasis kompetensi sekaligus berbasis karakter (competency and character based curriculum), yang dapat membekali peserta didik dengan berbagai sikap dan kemampuan yang sesuai dengan tuntutan perkembangan zaman dan tuntutan teknologi. Hal tersebut penting guna menjawab tantangan arus globalisasi, berkontribusi pada pembangunan masyarakat dan kesejahteraan sosial, lentur, serta adaptif terhadap berbagai perubahan. Kurikulum berbasis kompetensi dan karakter diharapkan mampu memecahkan berbagai persoalan bangsa, khususnya dalam bidang pendidikan, dengan mempersiapkan peserta didik melalui perencanaan, pelaksanaan, dan evaluasi terhadap sistem pendidikan secara efektif, efisien, dan berhasil guna. Oleh karena itu, merupakan langkah yang positif ketika pemerintah merevitalisasi pendidikan karakter dalam seluruh jenis dan jenjang pendidikan, termasuk dalam pengembangan Kurikulum 2013.

Pengembangan Kurikulum 2013 adalah melanjutkan Pengembangan Kurikulum Berbasis Kompetensi yang telah dirilis pada tahun 2014 dengan mencakup kompetensi sikap, pengetahuan, dan keterampilan secara terpadu. 
Dalam Kurikulum 2013 terdapat perubahan rancangan untuk peningkatan mutu pendidikan berupa kegiatan manajemen satuan pendidikan, pembelajaran dan penilaian, dan peminatan peserta didik. Kegiatan peminatan peserta didik merupakan bidang garapan profesi bimbingan dan konseling dalam satuan pendidikan (Farozin, 2014:1).

Kurikulum 2013 didefinisikan sebagai seperangkat rencana dan pengaturan mengenai tujuan, isi dan bahan pelajaran serta cara yang digunakan sebagai pedoman penyelenggraan kegiatan pembelajaran untuk mencapai tujuan pendidikan nasional serta kesesuaian dengan kekhasan, kondisi dan potensi daerah, satuan pendidikan, kompetensi lulusan pada satuan pendidikan, dan peserta didik (Marsigit, 2013:4).

Kurikulum 2013 lebih menekankan pada pendidikan karakter, terutama pada tingkat dasar yang akan menjadi fondasi bagi tingkat berikutnya. Melalui pengembangan Kurikulum 2013 yang berbasis karakter dan berbasis kompetensi, diharapkan bangsa ini menjadi bangsa yang bermartabat, dan masyarakatnya memiliki nilai tambah (added value), dan nilai jual yang bisa ditawarkan kepada orang lain dan bangsa lain di dunia, sehingga bangsa Indonesia bisa bersaing, bersanding, dengan bangsa-bangsa lain dalam percaturan global. Kurikulum 2013 betul-betul dapat menghasilkan insan yang produktif, kreatif, inovatif, dan berkarakter (Mulyasa, 2013:6-7).

Dalam implementasi Kurikulum 2013, pendidikan karakter dapat diintegrasikan ke dalam seluruh pembelajaran pada setiap bidang studi yang terdapat dalam kurikulum. Materi pembelajaran yang berkaitan dengan norma atau nilai-nilai pada setiap bidang studi perlu dikembangkan, dieksplisitkan, dihubungkan dengan konteks kehidupan sehari-hari. Dengan demikian, pendidikan nilai, dan pembentukan karakter tidak hanya dilakukan pada tataran kognitif, tetapi menyentuh internalisasi, dan pengalaman nyata dalam kehidupan sehari-hari.

Menurut Marsigit (2013:10), kegiatan pembelajaran dalam skema Kurikulum 2013 diselenggarakan untuk membentuk watak, membangun pengetahuan, sikap, dan kebiasaan-kebiasaan untuk meningkatkan mutu kehidupan peserta didik. Kegiatan pembelajaran diharapkan mampu 
memberdayakan semua potensi peserta didik untuk menguasai kompetensi yang diharapkan. Pemberdayaan diarahkan untuk mendorong pencapaian kompetensi dan perilaku khusus supaya setiap individu mampu menjadi pembelajar sepanjang hayat dan mewujudkan masyarakat belajar. Dengan demikian, guru diharapkan mampu mengimplementasikan metode pembelajaran yang inovatif (studentscentered); pembelajaran konvensional (teacher-centered) dianggap tidak lagi mampu memenuhi harapan-harapan di atas.

Keberhasilan implementasi Kurikulum 2013 dapat dilihat dari beberapa indikator, yaitu: (1) adanya lulusan yang berkualitas, produktif, kreatif, dan mandiri, (2) adanya peningkatan mutu pembelajaran, (3) adanya peningkatan efisiensi dan efektivitas pengelolaan dan pendayagunaan sumber belajar, (4) adanya peningkatan perhatian serta partisipasi masyarakat, (5) adanya peningkatan tanggung jawab sekolah, (6) tumbuhnya sikap, keterampilan, dan pengetahuan secara utuh di kalangan peserta didik, (7) terwujudnya pembelajaran aktif, kreatif, efektif, dan menyenangkan, (8) terciptanya iklim yang aman, nyaman, dan tertib sehingga pembelajaran dapat berlangsung dengan tenang dan menyenangkan, dan (9) adanya proses evaluasi dan perbaikan secara berkelanjutan (Mulyasa, 2013:11-12).

Dalam Kurikulum 2013, pemerintah akan mengubah kurikulum Sekolah Dasar, Sekolah Menengah Pertama, Sekolah Menengah Atas, serta Sekolah Menengah Kejuruan dengan menekankan aspek kognitif, afektif, psikomotorik melalui penilaian berbasis tes dan portofolio yang saling melengkapi. Basis perubahan kurikulum 2013 terdiri dari dua komponen besar, yakni pendidikan dan kebudayaan. Kedua elemen tersebut harus menjadi landasan agar generasi muda dapat menjadi bangsa yang cerdas tetapi berpengetahuan dan berbudaya serta mampu berkolaborasi maupun berkompetisi.

Adapun orientasi pengembangan kurikulum 2013 adalah tercapainya kompetensi yang berimbang antara sikap, keterampilan, dan pengetahuan, di samping cara pembelajarannya yang holistik dan menyenangkan. Perubahan yang paling mendasar adalah nantinya pendidikan akan berbasis science dan tidak berbasis hafalan lagi. 
Rencananya pada Kurikulum 2013 ini, pengurangan mata pelajaran sekolah akan terjadi di tingkat SD dan SMP. SMP yang semula mempunyai 12 mata pelajaran, pada tahun 2013 hanya akan mempunyai 10 mata pelajaran. Kesepuluh mata pelajaran tersebut yakni Pendidikan Agama, Pancasila dan Kewarganegaraan, Bahasa Indonesia, Matematika, IPA, IPS, Bahasa Inggris, Seni Budaya dan Muatan Lokal, Pendidikan Jasmani dan Kesehatan, dan Prakarya. Adapun dari sisi jam pelajaran, kurikulum baru ini akan menambah panjangnya jam pelajaran. Untuk SD kelas 1 dari 26 jam per minggu menjadi 30 jam. Untuk kelas 2 SD dari 27 jam menjadi 32 jam, sedangkan untuk kelas 3 SD dari 28 jam menjadi 34 jam, sementara kelas 4, 5, 6 SD dari 32 menjadi 36 jam per minggu. Untuk SD, terjadi perubahan dari 10 mata pelajaran menjadi hanya enam. Keenam mata pelajaran itu adalah Matematika, Bahasa Indonesia, Agama, Pendidikan Jasmani, Pendidikan Pancasila dan Kewarganegaraan, dan Kesenian. Sedangkan IPA dan IPS menjadi tematik di pelajaran-pelajaran lain.

Di tingkat SMP, pemberian pelajaran akan mempergunakan Tekonologi Informasi Komunikasi (TIK) di dalam kelas. Kebijakan ini memungkinkan pemakaian laptop di dalam kelas oleh siswa, dengan harapan, wawasan siswa dapat semakin terbuka. Sementara di tingkat SMA, siswa mendapatkan mata pelajaran wajib dan mata pelajaran pilihan. Dari sistem pendidikan ini, per jurusan di jenjang pendidikan SMA tidak dilakukan. Jumlah jam untuk siswa SMK hanya bertambah sekitar 2 jam per minggu. Khusus di SMK, penyesuaian jenis keahlian akan disesuaikan dengan kebutuhan pasar atau tren saat ini, namun seluruh siswa SMK ditiap jurusan akan mendapatkan mata pelajaran umum.

\section{Hambatan dan Tantangan Implementasi Kurikulum 2013}

Sebagai kurikulum yang relatif baru, Kurikulum 2013 akan menghadapi berbagai masalah dan tantangan dalam implementasinya, baik di tingkat nasional maupun dalam tatanan lokal. Ketika uji publik misalnya, pengembangan kurikulum ini sudah mendapat penolakan dari berbagai kelompok masyarakat pemerhati pendidikan. Demikian halnya di tingkat lokal, banyak guru, kepala sekolah, dan pengawas yang belum siap mengikuti perubahan. Masalah tersebut akan lebih mencuat ketika dikaitkan dengan berbagai pendapat tentang kelemahan-kelemahan dalam Kurikulum 2013. 
Kurikulum 2013 adalah kurikulum berbasis kompetensi yang pernah digagas dalam Rintisan Kurikulum Berbasis Kompetensi (KBK) 2004, tapi belum terselesaikan karena desakan untuk segera mengimplementasikan Kurikulum Tingkat Satuan Pendidikan (KTSP) 2006. Rumusannya berdasarkan pada sudut pandang yang berbeda dengan kurikulum berbasis materi, sehingga sangat dimungkinkan terjadi perbedaan persepsi tentang bagaimana kurikulum seharusnya dirancang. Perbedaan ini menyebabkan munculnya berbagai kritik dari yang terbiasa menggunakan kurikulum berbasis materi.

Beberapa ahli pendidikan mengidentifikasi beberapa kelemahan dalam Kurikulum 2013. Kelemahan pertama, Kurikulum 2013 bertentangan dengan Undang-Undang Nomor 20 Tahun 2003 tentang Sistem Pendidikan Nasional karena penekanan pengembangan kurikulum hanya didasarkan pada orientasi pragmatis. Selain itu, Kurikulum 2013 tidak didasarkan pada evaluasi dari pelaksanaan Kurikulum Tingkat Satuan Pendidikan (KTSP) 2006 sehingga dalam pelaksanaannya bisa membingungkan guru dan pemangku pendidikan. Kelemahan lainnya lainnya yaitu pemerintah seolah melihat semua guru dan siswa memiliki kapasitas yang sama dalam Kurikulum 2013. Guru juga tidak pernah dilibatkan langsung dalam proses pengembangan Kurikulum 2013. Selain itu, juga tidak adanya keseimbangan antara orientasi proses pembelajaran dan hasil dalam Kurikulum 2013. Keseimbangan sulit dicapai karena kebijakan Ujian Nasional (UN) masih diberlakukan. Kelemahan penting lainnya, pengintegrasian mata pelajaran Ilmu Pengetahuan Alam (IPA) dan Ilmu Pengetahuan Sosial (IPS) dalam mata pelajaran Bahasa Indonesia untuk jenjang pendidikan dasar. Langkah ini dipandang tidak tepat karena rumpun ilmu mata pelajaran-mata pelajaran itu berbeda (Damanik, 2012:1).

Menurut Marsigit (2013:1-2), terdapat beberapa tantangan yang dihadapi dalam implementasi Kurikulum 2013. Tantangan pertama yang muncul yaitu pada penerapan pendekatan sain. Pendekatan sain akan diberlakukan kepada semua mata pelajaran untuk semua jenjang. Salah satu wujud yang tampak nyata dalam penerapan metode sain muncul pada pedoman pengembangan RPP, yaitu sebagai EEK (Elaborasi, Eksplorasi, dan Konfirmasi) yang harus muncul pada setiap 
kegiatan pembelajaran, padahal secara psikologis dan filosofis, EEK belum tentu dapat diterapkan untuk semua disiplin ilmu, termasuk ilmu-ilmu humaniora.

Persoalan lain muncul dari digunakannya pendekatan tematik dan integratif. Walaupun pendekatan tematik dan integratif bukanlah hal baru dalam sejarah kependidikan di Indonesia, dalam implementasinya masih menjadi kendala besar. Tiga puluh tahun terakhir tidak pernah muncul wacana pembelajaran tematik dan integratif, sehingga hal demikian sebetulnya masih menjadi hal yang baru dan asing bagi sebagian besar guru.

Sebagian pengamat pendidikan juga menyangsikan klaim pemerintah bahwa penerapan Kurikulum 2013 akan menimbulkan efek kualitatif yang signifikan bagi kemajuan bangsa. Mereka berpendapat demikian karena masih terdapat berbagai kerancuan kompetensi inti dan dasar dengan materi dibiarkan kabur, dan kurikulum dilaksanakan sebelum matang. Kurikulum 2013 juga dipandang masih bermasalah jika dikaitkan dengan fondasi, visi, substansi, psikologis, dan filosofisnya. Hal ini menyebabkan pada ketidakjelasan arah pendidikan bangsa Indonesia ke depan.

Dari sisi persiapan, pemerintah dianggap tidak cermat, tidak sistematis, dan tidak mempunyai konsep yang akuntabel dan sustainabel dan hanya bersifat simtomatif sekadar menghasilkan kesibukan, misalnya penerbitan buku dan penataran instan. Selama ini masih terdapat persoalan imanen dalam mengubah paradigma lama (teacher-centered) menuju paradigma baru (student-centered). Berbagai peraturan dan kebijakan pemerintah tidak sinkron dan bahkan saling bertentangan satu dengan lain dalam mencapai mind-set yang dikehendaki seperti yang tertuang dalam Pasal 1 Ayat (1) UU Nomor 2 Tahun 1989 tentang Sistem Pendidikan Nasional (Sisdiknas).

Pandangan atau batasan keilmuan belum dijelaskan secara eksplisit, sehingga dari sisi hakikat keilmuan Kurikulum 2013 selama ini tidak mempunyai arah yang jelas pada setiap jenjang pendidikan. Pandangan keilmuan yang selama ini ada dan dijalankan hanya cocok untuk jenjang pendidikan tingkat tinggi. Hal ini berakibat belum adanya definisi mata pelajaran yang cocok untuk jenjang pendidikan yang lebih rendah seperti SMA, SMP, dan SD. Selama ini selalu diasumsikan bahwa mata pelajaran misalnya Biologi, Matematika, IPA, Geografi, 
dan sebagainya adalah sebuah body of knowledge, atau science of truth, atau structure of truth. Definisi tersebut hanya bermakna untuk jenjang pendidikan tinggi, sedangkan untuk pendidikan jenjang menengah dan pendidikan dasar, tidak bermakna.

Menurut Abduhzen (2014:1), penerapan Kurikulum 2013 sampai saat ini masih membutuhkan perbaikan, terutama pemahaman guru. Menurutnya, belum semua guru yang dilatih dan mengajar kurikulum baru sesuai dengan yang diharapkan. Karena itu, pelatihan guru akan menjadi pekerjaan berat bagi pemerintah. Apalagi pada 2014 pihaknya akan memberikan pelatihan kepada sekitar 1,3 juta guru yang tersebar di seluruh Indonesia. Sanggupkan pemerintah melakukan persiapan tersebut, mengingat faktanya saat ini pemahaman guru terhadap kurikulum baru belum memuaskan? Sedangkan, pemerintah hanya memiliki waktu paling lama satu semester untuk menciptakan tenaga-tenaga pendidik yang memahami Kurikulum 2013.

Secara yuridis formal, tujuan pendidikan sudah sangat jelas. Kurikulumkurikulum sebelumnya, tujuan filosofis pendidikan diarahkan secara parsial yaitu cenderung back to basic (SD), sertification dan transfer of knowledge. Sudah ada kesadaran pada Kurikulum 2013 untuk mengembangkan kreativitas dan kompetensi, namun hal tersebut belumlah cukup, karena secara filosofis tujuan pendidikan adalah mengembangkan ketrampilan hidup (life skill). Secara ontologis teori pembelajaran masih belum mengenai hakikinya; masih bersifat parsial dan sempit, yaitu ingatan, pemahaman, dan aplikasi (Teori Bloom). Teori Bloom ini mempunyai kekurangan, yaitu tidak mampu menjawab tantangan yang ada sesuai dengan perkembangan zaman. Teori pembelajaran seharusnya juga selaras dengan teori mengajar yang mengedepankan kegiatan eksplorasi, kemandirian, kemampuan bekerja sama, dan belajar kontekstual.

Dalam Kurikulum 2013 juga belum secara jelas disebutkan mengenai metode mengajar yang disarankan. Selama ini guru lebih dominan mengajar secara tradisional, yaitu transfer of knowledge. Kurikulum 2013 sudah mulai memunculkan eksplorasi tetapi belum secara implisit menuju keterampilan hidup. Selama ini praktik pembelajaran didominasi dengan textbook oriented. Walaupun sudah disarankan agar terdapat variasi sumber belajar, belum secara eksplisit 
disebutkan pentingnya pengembangan RPP dan LKS yang sesuai dengan paradigma explorasi dan membangun kecakapan hidup. Walaupun sudah disebut pentingnya portfolio dalam penilaian, nyatanya belum ada komitmen untuk menghapus UAN. UAN adalah sumber permasalahan pendidikan secara pedagogis. Sebaik apa pun penataran dan teori yang diperoleh dari kampus (LPTK) tetapi jika sudah terjun di sekolah, para guru hanya fokus pada metode pembelajaran yang berorientasi pada UAN. Bahkan kepala sekolah dengan tegas menyarankan guru agar tidak menggunakan metode yang macam-macam, dan hanya fokus pada pencapain UAN.

Hakikat siswa belum didefinisikan secara eksplisit. Selama ini semua pendidik dan pengambil keputusan dalam bidang pendidikan selalu menganggap siswa sebagai empty vessel, yaitu sebagai tong kosong yang harus diisi oleh guru. Kurikulum 2013 sudah mulai menyadari, tetapi belum secara eksplisit memberi solusinya. Belum didefinisikan mengenai hakikat kompetensi secara filsafati. Selama ini dan juga dalam Kurikulum 2013, tidak ada penjelasan bagaimana siswa atau guru membantu siswa mencapai kompetensinya atau memperoleh keterampilan membangun hidupnya.

Falsafat atau teori tentang sosial budaya tidak secara jelas dicantumkan. Negara kita dihadapkan pada persoalan tarik menarik antara pusat-daerah, sentralisasi-desenralisasi, dan monokultur-multikultur. Kebijakan pendidikan belum secara jelas dan terbuka bagaimana mengatur keseimbangan tersebut. Aspek konseptual belum secara eksplisit memberi gambaran tentang persoalan mendasar pendidikan.

\section{Pendekatan Kontruktivisme dalam Kurikulum 2013}

Kegiatan pembelajaran dalam skema Kurikulum 2013 diharapkan mampu memberdayakan semua potensi peserta didik untuk menguasai kompetensi yang diharapkan. Dengan demikian guru diharapkan mampu mengimplementasikan metode pembelajaran yang inovatif (students-centered), sedangkan pembelajaran konvensional (teacher-centered) dianggap tidak lagi mampu memenuhi harapan yang diinginkan.

Pengakuan keberagaman potensi siswa agar mereka mampu melakukan kegiatan eksplorasi berimplikasi terhadap perlaksaan kegiatan pembelajaran yang 
perlu menerapkan berbagai strategi dan metode pembelajaran yang menyenangkan, kontekstual, efektif, efisien, dan bermakna. Dengan demikian, Kurikulum 2013 sejalan dengan paradigma konstruktivisme dalam ilmu pendidikan. Kurikulum 2013 selaras dengan berbagai teori kependidikan, misalnya teori perkembangan kognisi dari Piaget, teori belajar dan membimbing dari Vygotsky, pendekatan kontekstual, kolaborasi, problem-based learning (Marsigit, 2013:10).

Salah satu inovasi pembelajaran menuju student-centered adalah pendekatan konstruktivisme. Dalam pendekatan konstruktivisme, siswa harus membangun pengetahuan dalam kerangka berpikirnya. Guru dapat memfasilitasi proses dalam mengajar dengan cara memberikan informasi yang bermakna dan relevan kepada siswa. Siswa diberi kesempatan untuk menemukan ide dari dalam dirinya, dan guru juga mengajarkan siswa untuk memiliki strategi belajar yang baik. Pendekatan ini menekankan peran aktif siswa dalam belajar, sehingga dikatakan bahwa strategi dalam konstruktivisme sering disebut sebagai studentcentered instructions. Dalam situasi kelas yang berpusat pada siswa, guru menjadi "guide on the side" dan "sage on the stage", membantu siswa menemukan pemaknaan terhadap materi serta mengontrol semua aktivitas di dalam kelas (Slavin, 2006:186).

Konstruktivisme merupakan pendekatan belajar yang dikembangkan oleh Piaget dan Vigotsky, dan beberapa filsuf seperti John Dewey, Thomas Kuhn, dan Karl Marx. Konstruktivisme merupakan perspektif psikologis dan filosofis yang memandang bahwa masing-masing individu membentuk atau membangun sebagian besar dari apa yang mereka pelajari dan pahami (Schunk, 2012:324).

Pada dasarnya, konstruktivistik memandang bahwa siswa belajar mengkonstruksikan struktur kognitif yang kompleks dan menginterpretasikan pengalamannya dalam situasi tertentu. Konstruktivisme mendorong pendidik untuk merekognisi nilai pengetahuan dan pemahaman yang membawa siswa untuk belajar, dan menyediakan pengalaman yang membantu siswa membangun pengetahuan di dunia (Krause dkk., 2010:188). Konstruktivisme memiliki asumsi yang senada dengan teori sosial kognitif yang menyatakan bahwa orang, perilaku, dan lingkungan berinteraksi secara timbal balik. 
Salah satu cara untuk mengorganisasikan pandangan-pandangan konstruktivis adalah membahas tentang dua bentuk konstruktivisme, yaitu: 1) psychological constructivism, yaitu menekankan pada pengetahuan, keyakinan, konsep diri, dan identitas selama proses pembelajaran; 2) social constructivism, menggambarkan keyakinan Vygotsky bahwa interaksi sosial dan konteks kultural merupakan bagian integral dari pembelajaran. Social constructivism memandang bahwa interaksi sosial membentuk perkembangan kognitif, dan merupakan komponen penting dalam proses belajar (Krause dkk. 2010:188).

Asumsi utama dari konstruktivisme adalah manusia merupakan siswa aktif yang mengembangkan pengetahuan bagi diri mereka sendiri. Untuk memahami materi dengan baik, siswa harus menemukan prinsip-prinsip dasar (Schunk, 2012:325). Lebih lanjut, Krause dkk (2010:189) menguraikan bahwa ketika menerapkan pendekatan konstruktivisme dalam kelas, perlu memahami prinsip dari pendekatan konstruktivisme, yaitu: 1) siswa merupakan partisipan aktif dalam belajar. "Learning by doing" merupakan kunci utama dalam praktik konstruktivisme; 2) siswa memiliki self-regulation, artinya mereka membangun dan memonitor sendiri proses belajar, dan strategi metakognisi memiliki peran besar dalam memfasilitasi regulasi diri; 3) interaksi sosial diperlukan dalam pembelajaran yang efektif. Piaget dan Vygotsky menyatakan bahwa interaksi sosial dengan teman sebaya, dan significant others (misal orang tua dan guru) berperan dalam perkembangan kognitif.; dan 4) konstruktivisme mendorong individu untuk memahami informasi bagi dirinya sendiri. Artinya dalam memahami suatu pengetahuan dapat dipahami secara berbeda oleh siswa lain.

Selanjutnya, prinsip pendekatan konstruktivisme dapat diterapkan dalam konteks di kelas yang menghasilkan strategi yang diharapkan: 1) mendorong pengalaman dan aktivitas yang berpusat pada siswa, di mana guru harus menyediakan waktu untuk memahami konstruksi pemahaman siswa yang dibangun dari pengalaman belajarnya. Guru penting memiliki ketrampilan untuk melakukan assessment karena fokus konstruktivisme terletak pada latar belakang pengalaman siswa, dan belajar sebelumnya, sehingga pendekatan ini menjadi multikultural dan perkembangan ideologi personal. Discovery learning dan inquiry merupakan dua cara yang dapat diterapkan dalam pembelajaran berfokus 
pada siswa; 2) menyediakan kesempatan siswa untuk bekerja sama. Dalam situasi kelas yang menerapkan pendekatan kontekstual, belajar memerlukan pengalaman, dan dengan bekerja sama dalam kelompok mendorong siswa untuk mendiskusikan gagasan dan belajar dari satu sama lain. Mengetahui bagaimana bekerja dengan orang lain, dan bagaimana membangun pengetahuan dan pengalaman yang berbeda akan memunculkan perspektif yang berbeda dalam berpikir, dan dapat membantu siswa memperluas kemampuan berpikir, dan menggali pendekatan baru dalam belajar. Ada beberapa strategi pembelajaran yang dapat digunakan untuk memunculkan situasi bekerja sama, antara lain cooperative learning, collaborative learning, dan peer-assisted learning; 3) membantu siswa mengembangkan keahlian. Tujuan utama pendekatan konstruktivisme adalah membantu siswa mengembangkan keahlian di bidang tertentu sehingga mereka diharapkan dapat menjadi lebih mandiri, dan otonom.

Di sisi lain, Driscoll dan Marshall (dalam Woolfolk, 2009:151) menyatakan bahwa pendekatan konstruktivisme merekomendasikan lima kondisi pembelajaran yaitu: 1) melekatkan pembelajaran di lingkungan pembelajaran yang kompleks, realistis, dan relevan; 2) menyiapkan negosiasi sosial dan tanggung jawab bersama sebagai bagian pembelajaran; 3) mendukung berbagai macam perspektif dan menggunakan berbagai macam representasi isi; 4) mengembangkan kesadaran diri dan pemahaman bahwa pengetahuan adalah sesuatu yang dikonstruksikan; dan 5) mendorong rasa memiliki dalam pembelajaran.

Penerapan pendekatan konstruktivisme di dalam kelas sesuai dengan harapan implementasi Kurikulum 2013. Menurut Marsigit (2013), dalam pembelajaran di kelas, guru dapat memberikan kemudahan dalam proses pembelajaran, dengan memberikan kesempatan peserta didik untuk menemukan atau menerapkan ide-ide mereka sendiri, dan mengajar peserta didik menjadi sadar dan secara sadar menggunakan strategi mereka sendiri untuk belajar, seperti ditulis dalam pedoman pelaksanaan sebagai berikut.

"Guru dapat memberi peserta didik anak tangga yang membawa peserta didik ke pemahaman yang lebih tinggi, dengan catatan peserta didik sendiri yang harus memanjat anak tangga tersebut. Bagi peserta didik, pembelajaran harus bergeser dari "diberi tahu" menjadi "aktif mencari tahu". Di dalam pembelajaran, peserta didik membangun pengetahuan 
bagi dirinya. Bagi peserta didik, pengetahuan yang ada di benaknya bersifat dinamis, berkembang dari sederhana menuju kompleks, dari ruang lingkup dirinya dan di sekitarnya menuju ruang lingkup yang lebih luas, dan dari yang bersifat konkrit menuju abstrak. Sebagai manusia yang sedang berkembang, peserta didik telah, sedang, dan akan mengalami empat tahap perkembangan intelektual, yakni sensori motor, pra-operasional, operasional konkrit, dan operasional formal".

Pernyataan di atas didukung oleh Schunk (2012) yang menguraikan bahwa pendekatan konstruktivisme telah mempengaruhi pemikiran dalam bidang pendidikan mengenai kurikulum dan pengajaran. Paham ini melandasi penitikberatan terhadap kurikulum terpadu di mana siswa mempelajari sebuah topik dari berbagai perspektif. Guru sebaiknya tidak mengajar dalam artian menyampaikan pelajaran dengan cara tradisional kepada sejumlah siswa. Guru seharusnya membangun situasi-situasi sedemikian rupa sehingga siswa dapat terlibat secara aktif dengan materi pelajaran melalui pengolahan materi-materi dan interaksi sosial.

\section{E. Peranan Self-Regulated Learning dalam Pendekatan Kontruktivisme}

Salah satu konsep dalam pendekatan konstruktivisme adalah selfregulated learning. Istilah lain dari self-regulated learning adalah self-regulated behavior, dan secara umum disebut sebagai self-regulation (Ormrod, 2006:103). Siswa yang memiliki regulasi diri menggunakan strategi belajar yang efektif. Zimmerman (2012) menguraikan bahwa self-regulation mengacu pada proses yang digunakan siswa untuk memfokuskan pikiran, perasaan, dan tindakan secara sistematis, untuk mencapai suatu tujuan. Self-regulation melibatkan aspek kognitif, dan afeksi, artinya bahwa ketika siswa terlibat dalam aktivitas belajar, siswa akan menjaga efikasi diri untuk belajar, meyakini akan memperoleh hasil yang maksimal dan tetap menjaga keadaan emosi (menikmati apa yang sedang dilakukan), sedangkan self-regulation melibatkan tindakan mengartikan bahwa siswa merencanakan dan mengatur perilakunya untuk mencapai suatu tujuan. Lebih lanjut, Zimmerman (2012) menyatakan bahwa self-regulation bukanlah suatu kemampuan mental atau keterampilan performance akademik, melainkan suatu proses self-directive dimana siswa mengubah kemampuan mental mereka ke dalam keterampilan akademik. Belajar dipandang sebagai aktivitas siswa yang 
dilakukannya sendiri dengan cara yang proaktif, dan menyadari akan kekuatan dan kekurangannya.

Siswa yang memiliki regulasi diri dalam belajar mampu menetapkan tujuan, merencanakan, dan menggunakan strategi belajar yang efektif. Sebaliknya, siswa yang regulasi dirinya rendah sering gagal dalam menerapkan strategi belajar yang efektif.

Ormrod (2006:104) menguraikan bahwa siswa yang memiliki selfregulated learning mampu: 1) menetapkan tujuan dan standar dalam performance siswa. Siswa yang memiliki regulasi diri mengetahui apa yang hendak dicapai. Pada umumnya, mereka melakukan kegiatan untuk mencapai tujuan yang ingin dicapai; 2) merencanakan tindakan untuk tugas belajar. Siswa yang memiliki regulasi diri mampu menentukan cara yang terbaik untuk menggunakan waktu dan sumber daya yang mereka miliki untuk tugas belajar. Mereka memilih strategi pembelajaran yang berbeda tergantung pada tujuan spesifik yang ingin dicapai; 3) mengontrol dan memonitor proses kognitif dan perkembangan selama belajar. Siswa yang memiliki regulasi diri terlibat selama proses pembelajaran. Siswa mencoba untuk memusatkan perhatian pada materi yang dipelajari dan berusaha membebaskan diri dari gangguan kognitif dan emosi. Untuk mengontrol dan memonitor proses kognitif, siswa menggunakan self-instruction dan selfmonitoring; 4) memonitor dan mencoba untuk mengontrol motivasi dan emosi siswa. Siswa yang memiliki regulasi diri mampu menjaga emosi yang dapat menghalangi performance siswa; 5) mencari bantuan dan dukungan. Apabila menemui kesulitan, siswa yang memiliki regulasi diri mampu mencari bantuan dan dukungan dalam membantu mengatasi kesulitan yang dihadapi; 6) mengevaluasi hasil dari usaha yang telah dilakukan. Siswa yang memiliki regulasi diri memiliki kemampuan untuk mengevaluasi hasil dari usaha yang telah dilakukan; 7) siswa mengalami peningkatan regulasi diri pada masa kanak-kanak, dan remaja. Peningkatan regulasi diri terjadi selama mengalami perkembangan dalam rentang kehidupan. Beberapa elemen regulasi diri yaitu menentukan tujuan, dan melakukan evaluasi diri, usaha secara sadar untuk memfokuskan perhatian, kemampuan untuk menyelesaikan tugas, merencanakan, dan memotivasi diri. Self- 
regulation meningkat karena adanya keterlibatan dalam aktivitas belajar, seperti membaca, mengerjakan tugas, dan menemukan formulasi.

Dalam self-regulated learning, siswa perlu diarahkan untuk mengatur diri sendiri dan berperan mengevaluasi kemajuan mereka, dan bertindak melampaui standar-standar yang disyaratkan bagi mereka dengan menelusuri hal-hal yang menjadi minat mereka (Slavin, 2006). Marsigit (2013:10) menguraikan bahwa siswa yang bersifat otonom, perlu diberi kesempatan untuk menemukan sendiri dan mentransformasikan informasi kompleks, mengecek informasi baru dengan aturan-aturan lama di dalam benaknya, dan merevisinya apabila aturan-aturan itu tidak lagi sesuai. Peserta didik harus didorong untuk mengkonstruksi pengetahuan melalui pengalaman-pengalamannya. Dengan demikian, Kurikulum 2013 sejalan dengan paradigma konstruktivisme dalam ilmu pendidikan. Kurikulum 2013 selaras dengan berbagai teori kependidikan, seperti teori perkembangan kognisi dari Piaget, dan teori belajar sosial dari Vygotsky.

\section{F. Penutup}

Meskipun terdapat beberapa kelemahan, penerapan Kurikulum 2013 memiliki keunggulan. Bagaimanapun Kurikulum 2013 mengandung pemikiranpemikiran untuk melakukan terobosan agar praktik pembelajaran di sekolah lebih baik yaitu menuju inovasi yang berorientasikan kepada siswa.

Kurikulum 2013 sebagai kurikulum nasional memuat Rasional, Struktur Kurikulum, dan Beban Belajar, Kerangka Implementasi, Silabus, dan Buku Babon untuk setiap jenis dan jenjang pendidikan, disusun sesuai program pendidikan nasional dengan kebutuhan dan potensi yang ada di daerah dan dituangkan dalam kurikulum daerah (Kurda), yang merupakan bagian dari Kurikulum Nasional.

Kegiatan pembelajaran dalam skema Kurikulum 2013 diselenggarakan untuk membentuk watak, membangun pengetahuan, sikap, dan kebiasaankebiasaan untuk meningkatkan mutu kehidupan peserta didik. Kegiatan pembelajaran diharapkan mampu memberdayakan semua potensi peserta didik untuk menguasai kompetensi yang diharapkan. Pemberdayaan diarahkan untuk mendorong pencapaian kompetensi dan perilaku khusus supaya setiap individu mampu menjadi pembelajar sepanjang hayat dan mewujudkan masyarakat belajar, sehingga diharapkan guru mampu mengimplementasikan metode pembelajaran 
yang inovatif (students-centered) sedangkan pembelajaran konvensional (teachercentered) dianggap tidak lagi mampu memenuhi harapan di atas. Pengakuan keragaman potensi siswa agar mereka mampu melakukan kegiatan eksplorasi berimplikasi terhadap pelaksanaan kegiatan pembelajaran yang perlu menerapkan berbagai strategi dan metode pembelajaran yang menyenangkan, kontekstual, efektif, efisien, dan bermakna.

Salah satu pendekatan pembelajaran yang tepat dalam penerapan Kurikulum 2013 adalah pendekatan konstruktivisme. Dalam pendekatan konstruktivisme, siswa harus membangun pengetahuan dalam kerangka berpikirnya. Guru dapat memfasilitasi proses dalam mengajar dengan cara memberikan informasi yang bermakna dan relevan kepada siswa. Siswa diberi kesempatan untuk menemukan ide dari dalam dirinya, dan guru juga mengajarkan siswa untuk memiliki strategi belajar yang baik. Pendekatan ini menekankan peran aktif siswa dalam belajar, sehingga dikatakan bahwa strategi dalam konstruktivisme sering disebut sebagai student-centered instructions. Untuk menekankan peran aktif siswa dalam belajar, diperlukan suatu strategi dalam regulasi diri dalam belajar pada siswa (self-regulated learning).

Dalam self-regulated learning, siswa perlu diarahkan untuk mengatur diri sendiri dan berperan mengevaluasi kemajuan mereka, dan bertindak melampaui standar-standar yang disyaratkan bagi mereka dengan menelusuri hal-hal yang menjadi minat mereka. Self-regulation bukanlah suatu kemampuan mental atau keterampilan performance akademik, melainkan suatu proses self-directive dimana siswa mengubah kemampuan mental mereka ke dalam keterampilan akademik. Belajar dipandang sebagai aktivitas siswa yang dilakukannya sendiri dengan cara yang proaktif, dan menyadari akan kekuatan dan kekurangannya. Siswa yang memiliki regulasi diri dalam belajar mampu menetapkan tujuan, merencanakan, dan menggunakan strategi belajar yang efektif. Sebaliknya, siswa yang regulasi dirinya rendah sering gagal dalam menerapkan strategi belajar yang efektif. 


\section{DAFTAR RUJUKAN}

Abduhzen, M. 2014. Pemahaman Guru Rendah. Tantangan Kurikulum 2013, (Online), (http://www.suaramerdeka.com/index.php/read), diakses 4 Mei 2014.

Damanik, C. 2012. Ini Kelemahan-kelemahan Kurikulum 2013, (Online), (http://www.edukasikompas.com/read/2012/12/19/12564532/ini.kelemaha n-kelemahan.kurikulum.2013), diakses 4 Mei 2014.

Farozin, M. 2014. Program Peminatan Peserta Didik Dalam Implementasi Kurikulum 2013. Makalah disajikan dalam Seminar Nasional Program Studi Bimbingan dan Konseling, FIP, IKIP PGRI Madiun, 4 Januari.

Hasan, S.H. 2004. Model Pengelolaan, Pemantauan, dan Penilaian Kurikulum dalam Kurikulum untuk Abad Ke-21. Jakarta: Gramedia.

Krause, K., Bochner, S., Duchesne, S. \& McMaugh, A. 2010. Education Psychology for Learning \& Teaching. Third Edition. Australia: Cengage Learning.

Marsigit. 2013. Tantangan dan Harapan Kurikulum 2013. Makalah disajikan dalam Seminar Nasional Matematika dan Pendidikan Matematika, Jurusan Pendidikan Matematika FPMIPA UNY, Yogyakarta, 18 Juni.

Mulyasa, E. 2013. Pengembangan dan Implementasi Kurikulum 2013. Bandung: Remaja Rosdakarya.

Ormrod, J. E. 2006. Essentials of Educational Psychology. New Jersey: Prentice Hall.

Schunk, D.H. 2012. Learning Theories. An Educational Perspective. Terjemahan Hamdiah, E. \& Fajar, E. 2012. Yogyakarta: Pustaka Pelajar.

Slavin, R.E. 2006. Educational Psychology: Theory and Practice. Eight Edition. Boston: Pearson.

Subandijah. 2003. Pengembangan dan Inovasi Kurikulum. Jakarta: Raja Grasindo Persada.

Sujoko. 2002. Perubahan Kurikulum dalam Pendidikan: Menuju ke Arah Pemahaman Kurikulum Berbasis Kompetensi. Makalah disajikan dalam Seminar Nasional Kurikulum Berbasis Kompetensi, IKIP PGRI Madiun, 02 April.

Sukmadinata, N. S. 2003. Prinsip dan Landasan Pengembangan Kurikulum. Jakarta: Dirjen Dikti. 
Sumantri, M. 2004. Pengembangan dan Pelaksanaan Kurikulum yang Menjamin Tercapainya Lulusan yang Kreatif (Berprakarsa dan Mampu Memecahkan Masalah) dalam Kurikulum untuk Abad Ke-21. Jakarta: Gramedia.

Suwandi, S. 2009. Penerapan Pendekatan Kontekstual (Contextual Teaching Learning) dalam Mengimplementasikan Kurikulum Berbasis Kompetensi. Retorika, 2 (2): 8-13.

Tedja, S. 2004. Hubungan antara Kurikulum Sekolah Menengah dengan Pendidikan di Perguruan Tinggi untuk Masa Depan dalam Kurikulum untuk Abad Ke-21. Jakarta: Gramedia.

Triyono. 2014. Paradigma Bimbingan dan Konseling dalam Sistem Pendidikan di Indonesia. Makalah disajikan dalam Seminar Nasional Program Studi Bimbingan dan Konseling, FIP, IKIP PGRI Madiun, 4 Januari.

Woolfork, A. 2009. Educational Psychology. Active Learning Edition. Tenth Edition. Terjemahan Soetjipto. 2010. Yogyakarta: Pustaka Pelajar.

Zimmerman, B.J. 2012. Becoming a Self-Regulated Learner: An Overview. Theory Into Practice, 41 (92): 64-70. 